\title{
EFFECTS OF LEARNING STYLES ON CAREER PREFERENCES OF SENIOR SECONDARY SCHOOL STUDENTS IN JIGAWA STATE, NIGERIA.
}

\author{
SARA, Safyanu Shuaibu \\ Jigawa Educational Resource Centre \\ Ministry of Education, Science and Technology \\ Dutse, Jigawa State. Nigeria \\ e-mail: ssara73@hotmail.com
}

\begin{abstract}
The research investigated the effects of learning styles on career preferences of senior secondary school students in Jigawa State, Nigeria. A total of six hundred students, three hundred and sixty male, and two hundred and forty female were randomly selected from ten senior secondary schools across the state for the study. Two different data collection instruments were used to gather data for the research'. These are Kazembe Sorting Test (KST) and Vocational Interest Inventory (VII) to test learning styles, and career preferences respectively. Chisquare, was used to find the effect of independent variable (learning style) and dependent variable (career preference). The findings of the study revealed that: There is significant sex difference in learning styles; there is significant sex difference in career preference. Significant differences do exist between field dependents and field independent subjects (student). Finally, recommendations were offered for appropriate counselling practice on the students having varieties of learning styles.
\end{abstract}

Key Words: Learning style, career preference, field dependent, field independent.

\section{Background to the Study}

Learning is the sum total of an individual's life experience acquired through socialization process. It exceeds a mere acquisition of factual information or the mastering of skills, as it also includes the sum total of an individual's life experience which are relatively permanent in nature and which have survival value for him (Mukherjee, 2002). To Eggen \& Kauchak (2002), learning can generally be classified either as conscious or unconscious' the former is a situation where an individual learns certain things deliberately, while latter type is a situation where one learns without any deliberate effort. 
Yakasai (1991) opined that a casual observation of a group of people confronted with common problem will show how diverse people differ in their approach towards solving it. While some will approach the task systematically, others are bound to approach it in a haphazard manner. Yakasai (1991) further stated that while some take longer period of time before deciding on the best cues to employ in solving the problems, others will be hasty in their quest and attempt to solve it. All these, according to Yakasai illustrate the individual's style at problem solving. As young children who are not matured their initial approaches to problem solving gradually transform into kind of pattern of behaviour and this is termed their learning style.

In popular usage, the term style-is most often equated with strategy," a development that prompted psychologists like Riding \& Read (1996) to draw a distinction between the two similar terms. The above authors maintained that a person's "learning style" may be equated with his characteristic way of thinking or of approaching a problem while a learning strategy is a particular approach employed to solve a narrower range of problems. Bichi (1998) added that while an individual's learning styles remain more or less stable over the years, his strategy may vary from one situation to another. Hence strategies are less stable and it could be concluded that style is a product of one's experience with the numerous strategies one uses in solving day to day problem overtime.

From the above discourse, it is discernible that learning style refers to the consistencies in an individual's mode of functioning in a variety of behavioural situations. Bichi (1998) stated that learning style is a hypothetical construct developed to explain the process of mediation between stimuli and responses and that it is the characteristic ways in which individuals conceptually organized the environment. It is the way as further stressed by Bichi (1998), an individual filters and processes stimuli so that the environment takes on psychological meaning.

Riding \& Read (1996) sees learning style as the manner in which an individual comes to grips with reality. Bichi (1998) again defined the term in terms of consistent pattern of organizing and processing information. Yakasai (1991), citing Riding and Caine (1993), again defines learning style as a rather special form of perceptual spatial ability of an individual to separate figure from the ground. Yakasai further refined the meaning of learning style to imply the way an individual thinks rather than the content of his thinking, that is, how an individual thinks whether clearly or vaguely, reflectively or impulsively deeply or 
shallowly, cover gently or divergently, rigidly or flexibly when confronted with a problem.

Bichi identified nineteen categories to the study of learning styles. Among the widely known construct identified is that of field dependence - independence put forward by Witkin (1962). Other popular dimensions include the reflective - impulsive, holistic - analytic scanning - focusing, verbal - imaginary, global - articulated, levellers, and sharpeners. Other classes identified by him are convergent divergent, constructed flexible, weak - strong. Field dependents student according to Bichi are those who usually think rationally in problem solving ability while the field independents are those who think irrationally when confronted with problem.

Career preference is the other variable under consideration. Ogunsaju (1984) cited on Mbruza (2002) defined career as a regular occupation or profession in which one is making a living a living. Kochar (2002) considers career preference as the occupation with the highest positive valence among alternative form of work value.

Okon (2001) is of the view that economic development and incentives in a country dictate occupational choice. He maintained that in primitive societies choices are highly curtailed or non-existent while in developed economies the possibilities of choices are much greater. He further indicated that in the earlier times when our economy was relatively young some types of occupation and profession are totally unheard, for instance fields such as garbage collection, public relations, beauticians, internal decoration, real estate, journalism, pharmacy, professional footballers and dietician. Equally, economic incentive that is the range of earnings attracted by different occupations very high determines career preference. Simply put those occupations that have higher pay attract a lot of people. Okon (2001).

Mburza (2002) viewed, career preference as a direct result of political development within a given polity. Mburza further stated that in the 60's there was an influx into the administrative position by professional from all fields to fill the vacuum created by the departure of colonial masters. He again observed that protracted military rule and their squander mania had led many young people to aspire for career in army, in other words political development in any country dictates the type of occupation to be in demand. Mburza concluded that the current political atmosphere and complexities had also open "flood gate" to many varied careers. 
Kochar (2002) observed that another greatest influence on the career preference is the society itself. He further indicated that an individual's interest and talent may be towards certain field. For example, teaching, but the society's attitude towards this noble profession may force the individual to Sublimate into the society's approved fields like the fashionable $(\mathrm{ABC})$, army, banking and custom services which are socially recognized as viable fields.

A family's background and religious beliefs, according to Kochar (2002), is also considered as another major factor in career selection. Kochar believed that an individual's family can sanction his vocational choice. For instance where parents are devout Muslims, a child can never harbour the ambition of becoming a brewer or from such home a daughter to nurse a modelling ambition. Related to this closely, there is also the belief to Mburza (2002) and Kochar (2002) that career choice among youths is also affected by socio-economic status of their parents. The authors opined that where the parents belong to aristocracy or nobility stratum, their children could hardly aspire to be preachers, musicians, garbage collectors or anything beneath their prestige. There is also the general argument of the practices of inter-generational mobility of labour among elites. That is to say, lawyers, engineers, physicians, kings, architect; footballers etc. all groomed their field so as to ensure continuity of their trades within families from one generation to the next.

Another variable considered by Okon (2001) to exert a considerable influence on career preference is intelligence. Okon believed that while bright chaps for science oriented career, the mediocre opt for career within humanities, while weaker children aspire for arts biased and technical vocation. Physique' was viewed as a leading factor in career aspiration. Okon opined that it sanctions entry into certain fields of endeavour. He further stated that no matter how talented a child may be, career in the military and paramilitary may be outside his/her range if he/she failed to attain some predetermined height or weight.

At this juncture, it is understood; however that one's leaning style usually influences one's career choice and preference. However, while some individuals tend to experience in totality (i.e. field perceivers), the field dependent tend to prefer, in most cases, artistic and social services as well as humanities; the field independent subjects, on the other, hand tend to prefer mechanical and scientific careers.

\section{Statement of the Problem}

In the current democratic era education is considered not only worthwhile but essentially important and sine-qua-non for top position, 
as such there is mad rush acquire it. It is therefore a great concern to see and involve ourselves in finding ways in which our young generation students will be adjusted Nigeria youths are today challenged by personality mal adjustment, ignorance of career prospects (NPE 2004) and therefore suffer greatly in their quest for "diploma disease" in view of vocational and career preferences and choice for survival thereby rushing to the white collar job not considering their ability.. These usually aid in bringing about non smooth transition from school to work which is mostly considered as disaster to the society.

On the process, elders, government and counsellors use their human and material resources to provide smooth transition from school to work. All these proved relatively little knowledge about adolescent learning style, a phenomenon which seriously shapes an individual's career preferences. Inadequate knowledge of learning style and its effects on career preference is the problem which this study set to investigate.

\section{Purpose of the Study}

The aims and objectives of this study can be stated as follows:

1. Determine if there is any relationship between learning styles and career preference

2. Determine if there is any gender difference in learning style

3. Determine whether there is gender difference in career preference

\section{Hypotheses}

The study was also aimed at testing the following three hypotheses:-

$\mathbf{H O}_{1}$ : There is no significant difference in career preference between field dependents

$\mathrm{HO}_{2}$ : There is no significant sex difference in learning styles among the student of Jigawa state senior secondary schools.

$\mathbf{H O}_{3}$ : There is no significant sex difference in career preference among the senior school students of Jigawa state.

\section{Significance of the Study}

The findings of this study will be of great help to counsellors in helping the students to make right choices considering their talents and abilities. The findings of the study will also go of a long way in checking the problem of wrong allocation of most precious resource, "labour" a problem which usually brings about and employment. Finally, if 
learning style is the individual's preference in mode of problem solving factor, then need for an investigation in this field and career development will be revealing.

\section{Scope of the Study}

The scope of the study is limited to only senior secondary school students within Jigawa state. The aim is to assist students to scale through development tasks characterized by this stage. This includes styles of learning, choice of career and preparation for vocation.

\section{Methodology}

The research used "expost-facto" quasi experimental design. Osuala (2001) and Best and Khan. (2005) asserted that "expost factor design directs the investigation to identify two or more groups which differ in variables such as personality, intelligence and creativity. Ezeji (2004) also indicated that once the groups have been identified and selected one variable is related to non manipulated variable.

The population of the study was drawn from all the senior secondary school students in Jigawa state. The number of students in Jigawa state senior secondary schools, according to ministry of education report, is about fourteen thousand four hundred and thirty two $(14,4320)$. However, out of the population, six hundred (600) were used as the sample of the study using the sample table provided by Kreycie and Morgan (1971), ten senior secondary school were randomly selected. The participants were also selected using simple random sampling techniques. The male students selected were 360 while the females were 240 in number.

\section{Instruments}

The instruments used in the study are Kazembe Sorting Test (KST) to test learning styles and Vocational Interest Inventory (VII) to test career preference. Kazembe Watson an African psychologist who modified embedded figure test and Kaganis original sorting test. The modified Kazembe test was to measure* field dependence and field independence. It was to suit Africa and was adopted and used in a manner of studies like that of Yakasai (1991), Serio (1998) and Sara (2004).

The KST consists of 16 items each comprising 13 pictures in which every respondent was asked to sort out two pictures in which he/she thinks go together to give reasons for selection. It was developed in Rhodesia using a sample of seven hundred pupils. A test retest was used to determine the reliability of KST by Kazembe with one hundred and 
fifty students from the original sample. A co-efficient of 0.09 was found which is sufficient enough, according to Nwogu (2006), for the study. As for scoring, Kazembe considered a score of 1-9 for field dependent and 10-16 for field independent. This is also adopted in the current study. The instrument was used in a number of studies in Nigeria like that of Yakasai (1991), Serio (1998) and Sara (2004).

The VII is an instrument invented by Christopher M. Bakare, $\mathrm{PhD}$ of University of Ibadan. It was designed to help an individual indicate the type of vocation he/she is interested in and would enjoy doing. It consists of 100 items, 10 for each of the ten interest areas, namely mechanical, scientific, outdoor, artistic, persuasive, literacy, musical, social services, computational and clerical. The individual (VII) tends to tell his interest profile. The reliability of VII has been established for Nigerian subjects (Bakare, 1977). The reliability figure for one group of students range from 0.57 for the artistic to 0.92 for the scientific interest areas, for another group of students, the reliability co-efficient falls between 0.63 for persuasive and 0.91 for literacy interest areas.

In this study however, four (4) out of ten interest areas were used. Interest areas of mechanical, social service, scientific and artistic were those items used in the VII. In these forty indirect statements were used, above each one five (5) options were made for which each of the student's sample is required to circle the most appropriate option of his/her choice, the options were numbered five to one (5-1) thus:-

$\begin{array}{ll}\text { Like very much } & 5 \text { points } \\ \text { Like } & 4 \text { points } \\ \text { Indifferent } & 3 \text { points } \\ \text { Dislike } & 2 \text { points } \\ \text { Dislike very much } & 1 \text { point }\end{array}$

\section{Data Collection Procedure}

The researcher used five weeks to go round the schools. The participants were gathered in separate classrooms, clear information, instruction and guidance were given to them as an orientation. They were asked to finish the work in an hour and the data was collected. The researcher employed the services of the career masters of the schools chosen. Chi-square was used as the statistical instrument to analyze the data. The $\mathrm{X}^{2}$ tests are frequently used because behavioural researchers are often interested in counting the number of subjects falling into particular categories (Shavelon 1981). 


\section{Results and Discussions}

Table 1: $\quad$ Male/Female FD and FID

\begin{tabular}{|c|c|c|c|c|}
\hline S/NO & SEX & FD & FID & TOTAL \\
\hline 1 & No. of male & 165 & 195 & 360 \\
\hline 2 & No. of female & 134 & 105 & 240 \\
\hline & Total & $\mathbf{2 9 9}$ & $\mathbf{3 0 1}$ & $\mathbf{6 0 0}$ \\
\hline
\end{tabular}

Table 1 clearly shows the distribution of male/female field dependent and independent subject. This is the summary of the whole data of the study.

$\mathrm{HO}_{1}$ : There are no significant differences in career preference between field dependent and field independent students in Jigawa State senior secondary schools.

The vocational inventory (VII) tests scores of both groups' subjects are obtained and computed in $X$. Table 2 shows the analysis.

Table $2 \quad X^{2}$ Analysis Field Dependent and Field Independent Subjects on Career Preferences.

\begin{tabular}{|l|c|c|c|c|c|c|}
\hline & Mech. & Scientific & Artistic & s/services & Total & Result \\
\cline { 1 - 6 } FID & $87(76.25)$ & $82(76.25)$ & $66(75.25)$ & $65(73.24)$ & 301 & \\
\cline { 1 - 6 } FD & $65(75.25)$ & $70(75.25)$ & $84(74.75)$ & $81(72.76$ & 299 & \multirow{2}{*}{7.96} \\
\cline { 1 - 6 } Total & $\mathbf{1 5 2}$ & $\mathbf{1 5 2}$ & $\mathbf{1 5 0}$ & $\mathbf{1 4 6}$ & $\mathbf{6 0 0}$ & \\
\cline { 1 - 5 }
\end{tabular}

(The figures in parenthesis are the expected frequencies).

The result of the above statistics shows that there is significant difference in career preference between field dependent and field independent students in Jigawa State senior secondary schools. The $\mathrm{X}^{2}$ calculated is 7.96 which is less than the $\mathrm{X}^{2}$ critical given in the table which is 7.82 at 0.05 level of significance at $\mathrm{df}=3$. This indicated that there is difference in career preference between field dependents and field independents students.

$\mathrm{H}_{2}$ : There is no significant sex difference in learning style between male and female students in Jigawa State senior secondary schools.

To test this hypothesis, frequency scores of the subject's ion Kazembe sorting test was obtained. The subjects are 600 , using zero to nine (0-9) 
and (10-16) of KST scores for both the FD and-FID respectively (field dependent). As such two hundred and ninety nine field dependents were identified; this is subject to scoring from 1-9 in the KST, while three hundred and one were identified to be field independent whose score was from ten to sixteen (10-16).

Table 3: Frequencies of each category of Learning Style for the Male and Female subjects.

\begin{tabular}{|l|c|c|c|c|}
\hline \multicolumn{1}{|c|}{ Sex } & $\begin{array}{c}\text { Field } \\
\text { Independent }\end{array}$ & $\begin{array}{c}\text { Field } \\
\text { Dependent }\end{array}$ & Total & Result \\
\hline Males & 195 & 165 & 360 & $\mathrm{X}^{2}$ cal - 5.76 \\
\hline Females & 106 & 134 & 240 & $\mathrm{X}^{2}$ crit -3.84 \\
\hline Total & $\mathbf{3 0 1}$ & $\mathbf{2 9 9}$ & $\mathbf{6 0 0}$ & $\mathbf{5 . 7 6}>\mathbf{3 . 8 4}$ \\
\hline
\end{tabular}

From table 3, the computed $X=5.76$, while the critical $X=3.84$ which is less than the computed $X$ at 0.05 level of significance and $\mathrm{df}_{1}$, this means that there is significance difference in learning style between male and female students in Jigawa State senior secondary schools. While male are field independent, females are more of field dependents as such the above null hypothesis is there by rejected.

$\mathrm{HO}_{3}$ : There is no significant sex difference in career preferences between males and females senior secondary school student in Jigawa State secondary schools.

To test this hypothesis the vocational interest inventory (VII) score of both male and female subjects was obtained according to the preference area and computed into $\mathrm{X}^{2}$ table 4 contains the analysis.

Table 4: $\quad$ Frequencies of Male and Female Subject on Care Preferences

\begin{tabular}{|l|c|c|c|c|c|c|}
\hline \multicolumn{1}{|c|}{ Sex } & Mech. & Scientific & Artistic & s/services & Total & Result \\
\hline FID & $96(86.13)$ & $02(86.13)$ & $87(85.57)$ & $85(82.17)$ & 360 & $\mathrm{X}_{\text {cal }}^{2}=1.39$ \\
\hline FD & $56(65.87)$ & $58(65.87)$ & $64(65.87)$ & $62(65.38)$ & 240 & $\mathrm{X}_{\text {crit }}=7.85$ \\
\hline Total & $\mathbf{1 5 2}$ & $\mathbf{1 5 0}$ & $\mathbf{1 5 1}$ & $\mathbf{1 4 7}$ & $\mathbf{6 0 0}$ & $\mathbf{P}=\mathbf{0 . 0 5} \mathbf{d f}=\mathbf{3}$ \\
\hline
\end{tabular}


Table 4 shows that the $\mathrm{X}_{\text {cal }}^{2}=1.39$ while the $\mathrm{X}^{2}$ crit $=7.85$ at 0.05 level of significance which calls for the acceptance of null hypothesis which says there is no significant difference in career preference among males and females senior secondary school students in Jigawa State.

\section{Discussion of Findings}

Hypothesis one stated that statistical differences exist in terms of career preference between field dependent and field independent students. Whereas field dependent prefer Artistic and social services, field independent prefer scientific and mechanical vocational areas. This finding goes in line with that of Yakasai (1991) who found out that field dependent subjects showed high attitudes toward social studies which is the bedrock of artistic and social sciences while field independent students showed high interest toward integrated science which the bedrock of scientific and mechanical career areas.

Hypothesis two stated that there is no significant sex difference in learning styles among the subjects. Here the findings revealed that difference among male and female subjects were found. Males are more of field independent while females are more of field dependents. This, finding is contrary of that of Yakasai (1991) who stated that in recent times though field dependents and field independents can be found in both sexes, the child rearing practices and religious implications in the study area tends to make both male and female differ in learning style.

Hypothesis three stated that there is no significant gender difference in career preference. The findings revealed that significant difference in career preference do exist between male and female students of Jigawa State senior secondary schools. As male students are more of field independents therefore prefer scientific careers, the females are more of field dependents preferring mostly artistic careers. This finding is in line with that of Riding and Read (1996) who pointed out that previously known gender bias in subjects was confirmed. They further concluded that females are encouraged to engage in domestic related areas, males are encouraged to go for the heavy duties. Females therefore prefer, in most cases, home economics and socially related subjects.

\section{Conclusion}

In line with the findings of this research the following specific conclusions are drawn: -

1. Student's particular learning style greatly affects his choice or preference of one career over the other. 
2. Female students tend to incline to artistic related careers because they are field dependents

3. Male students select scientific related careers simply because they are field independents

4. Sex difference in learning style exists among the senior secondary school students in Jigawa State as well as career preference.

\section{Recommendations}

Based on the finding of this study the following recommendations are offered:-

1. Different kind of reinforcements by Counsellors should be encouraged to modify and foster field dependent and field independent social and future career

2. Counsellors should also use different types of techniques bearing in mind the nature of students, learning style and performance.

3. Counsellors need also to take note on the findings of this study and ensure that proper placement is being made. School authorities however need to give room to counsellors to perform these respective counselling duties. Students who are good in science should be restricted to sciences also with arts; cross placement must therefore be avoided.

\section{References}

Bichi, M.Y. (1998). Human Learning: Basic Concepts and Structural Strategies, Kano: Debesco Press.

Eggen, P \& Kauchak, D. (2002). Educational Psychology 5'f Edition. Windows on Classrooms Merrill Prentice Hall: New Jersey.

Ezeji, S.C. (2004). Basic Principles of Research in Education: Enugu Cheston Adenly Ltd.

Kreycie \& Morgan. (1973). Determining Sample Size for Research Activities, Educational and Psychologist Measurement Vol. 3

Mburza, A. (2002). Relationship between Family Background and Occupational Choice of Senior Secondary School Students, Borno State, Nigeria. Unpublished PhD Thesis, University of Maiduguri.

Mukherjee, A. (2002). Educational Psychology. (Revised Edition) Zaria: S. Asekome \& Publishers.

Myers, D.G. (1993). Exploring Psychology. (2nd Edition) New York: Worth Publisher. 
Nworgu, B.G. (2006). Educational Research: Basic issues and methods Ibadan: Wisdom Publishers Ltd State Hospital Road, Nigeria.

Ofo, J.E. (1994). Research Method and Statistics in Education and Social Sciences. Lagos: Toja Education Research and publishers Ltd.

Okon, S.E. (2001). Education and Work: Career Planning and Decision Making, Zaria: Ahmadu Bello University, Press Limited (Pp 120 123).

Riding, R.J. \& Read, G. (1996). Cognitive Style and Pupils Learning Preference in Educational psychology (Ed) Richard J. Riding and K, Whadel 16 (1) 81 - 106 (Carfax).

Riding, R.J., \& Wright, M. (1995). Cognitive Style, Personal Characteristics and harmony in Students Flats, In Educational Psychology, An International Journal of Experimental Psychology (Ed) R.J, Riding-and K, Whadel 15 (3) 351 - 349 Carfax.

Yakasai, M.I. (1991). Relationship of Cognitive Style to Child Learning Practices among Urban and Rural Hausa Students. Unpublished M.Ed. Thesis, Bayero University, Kano. 